\title{
Stem damages caused by heart rot and large poplar borer on hybrid and European aspen
}

\author{
Martins Zeps, Silva Senhofa, Mara Zadina, Una Neimane \\ and Aris Jansons*
}

Zeps, M., Senhofa, S., Zadina, M., Neimane, U., Jansons, A. 2017. Stem damages caused by heart rot and large poplar borer on hybrid and European aspen. - Forestry Studies | Metsanduslikud Uurimused 66, 21-26. ISSN 1406-9954. Journal homepage: http://mi.emu.ee/forestry.studies

\begin{abstract}
Solid wood production of hybrid aspen requires relative longer rotation periods, thus increasing risk of wood damages by pests and diseases. We compared damages by heart rot and poplar borer of 48 years old hybrid (Populus tremuloides Michx. $\times$ P. tremula L.) and European aspen in a progeny trial located in Eastern part of Latvia. Trees were harvested and rot patches and galleries were recorded and measured at a stump level. The number of galleries had positive relation on number of patches and total area of rot. The susceptibility of the rot and poplar borer was similar for both hybrid and European aspen. Yet, some differences among families were detected. No effect of pathogens damage was observed on the tree growth. Larger trees had smaller proportion and incidence of rot and galleries per unit of area as well as wider outer rot-free wood layer.
\end{abstract}

Key words: Populus tremula, Populus tremuloides $\times$ P. tremula, wood damages, heart rot, Saperda carcharias.

Authors' address: Latvian State Forest Research Institute 'Silava', Rigas str. 111, Salaspils, LV-2169, Latvia; *e-mail: aris.jansons@silava.lv

\section{Introduction}

Since the end of the $20^{\text {th }}$ century, main production goal for fast-growing hybrid aspen (Populus tremuloides Michx. $\times$ P. tremula L.) has been energy wood (Rytter \& Stener, 2005). However, growth characteristics of hybrid aspen allow flexibility in rotation period and solid wood can be produced.

The use of resistant clones may not be necessity for biomass production (Steenackers et al., 1996) where short rotations allow avoiding diseases and pest caused wood damages and high quality (mechanical strength) of wood is not needed. However, rotation period for solid wood production is 20-30 years (Hynynen et al., 2004; Rytter \& Stener, 2005) and risk of wood damages and reduced growth due to diseases and pests increases. For instance, reduction of height growth has been observed due to the large poplar borer Saperda carcharias L. damage and rot associated with it (Cramer, 1954; Välimäki \& Heliövaara, 2007). Damaged trees become less vigorous, and trees fall behind in growth (Mattson et al., 1988). In addition, maintaining resistance interferes with growth (Osier \& Lindroth, 2006): productive trees allocate more resources for the growth, thus they may be more susceptible to pests and diseases (Osier \& Lindroth, 2006). Additionally, the large poplar borer is most abundant in well-lit, low-density stands on vigorous trees (Šrot, 1962), thus may cause more damage in plantations. Due to mechanical damage by poplar borer, trees are more prone to wind (DeBell et al., 1997) and poplar borer might introduce the 
rot into the tree. Phellinus tremulae (Bond.) Bond. et Boriss. is unusually aggressive rot, specialized for both trembling and European aspen, and cause more wood volume loss than other diseases (Newcombe $e t$ al., 2001). Moreover, decay and discoloration can be major defects limiting the end use of timber (Eckstein et al., 1979).

Tree breeding has mainly focused on superiority in terms of growth and stem quality paying less attention to resistance to diseases (Steenackers et al., 1996). Populus hybrids, including hybrid aspen, with remote origin of parent trees are reported to be prone to diseases (Ilstedt \& Gullberg, 1993). Resistance to diseases for Populus is highly heritable (Newcombe \& Bradshaw, 1996), including these for decay and discoloration traits (Eckstein et al., 1979). Yet, main focus has been on Hypoxylon and Melampsora caused diseases (DeBell et al., 2002). In the recent past a few studies have been done in relation to pest and disease resistance for hybrid aspen (Tullus et al., 2012), among which Välimäki \& Heliövaara (2007) have focused on rot and poplar borer damages in Finland.

The aim of this study was to assess susceptibility of hybrid aspen to rot and poplar borer in comparison to European aspen. We hypothesized that hybrid aspen is more prone to both rot and poplar borer due to faster growth.

\section{Material and Methods}

This study was based on a progeny trial located in Eastern part of Latvia, near Kalsnava (56 $\left.40^{\prime} \mathrm{N}, 2^{\circ} 58^{\prime} \mathrm{E}\right)$. The stand was established on a former agricultural land on sod-podzolic mineral soil with normal moisture regime, corresponding to $O x$ alidosa forest type. In 1966, three-year old saplings of seven provenances of native European aspen $P$. tremula and seven families of hybrid aspen $P$. tremuloides $\times P$. tremula were planted at a $3 \times 3 \mathrm{~m}$ grid. All hybrid aspen families were progenies of the same mother-tree growing in botanical garden in central part of Latvia (no information on its origin is available) and seven local plus trees from different regions of Latvia. In the winter 2013/2014, height and the diameter at breast height $(\mathrm{DBH})$ was measured for each tree. A year later, the stand was harvested by clearcut at age of 48 years. In total, 43 aspen and 129 hybrid aspen trees from five families, representing DBH distribution (ranging from $18 \mathrm{~cm}$ to $43 \mathrm{~cm}$ ) of the trial for respective families, were sampled. On stumps, aspen heart rot (patches located both in central and periphery part of the stump), caused by fungus $P$. tremulae and galleries, created by poplar borer S. carcharias (part of them was enclosed by the rot), were found. To measure the defects, a polythene film was mounted on the selected stump. Perimeter of stump, rot patches and galleries were projected on a film with a black marker. In the laboratory, area of stump, central and peripheral rot, and galleries were measured from film using planimeter (PLANIX 10S, Tamaya Inc., Japan). Total number of galleries and those enclosed by rot were counted. The distance from bark to the outermost gallery and rotten patch was measured.

Normality of data was assessed by Shapiro-Wilkinson test. ANOVA was used to assess the effect of "species" and family on the height. The effect of "species", family and DBH group as independent variables on the response parameters other than tree height was assessed using non-parametric Kruskal-Wallis test. The differences between groups were tested using Dunn's multiple comparison. $P$-values were adjusted using the Bonferroni transformation (Sokal \& Rohlf, 1995). Spearman rank correlation was used to assess the relationships between the measured variables. All tests were performed at $\mathrm{a}=0.05$. All calculations were done in R 3.4.0. (R Core Team, 2016). 
Table 1. Mean values of stem parameters and wood damages ( \pm confidence interval).

\begin{tabular}{|c|c|c|c|c|c|c|c|}
\hline Group & $\begin{array}{c}\text { Mean DBH, } \\
\mathrm{cm}\end{array}$ & $\begin{array}{c}\text { Mean } \\
\text { height, m }\end{array}$ & $\begin{array}{c}\text { Mean area } \\
\text { of rot } \\
\text { per stump, } \\
\mathrm{cm}^{2}\end{array}$ & $\begin{array}{l}\text { Mean propor- } \\
\text { tion of rot } \\
\text { per stump, \% }\end{array}$ & $\begin{array}{l}\text { Number of } \\
\text { rot patches } \\
\text { per stump }\end{array}$ & $\begin{array}{l}\text { Number of } \\
\text { galleries } \\
\text { per stump }\end{array}$ & $\begin{array}{l}\text { Number of } \\
\text { galleries } \\
\text { enclosed by } \\
\text { rot per stump }\end{array}$ \\
\hline Family A & $29.8 \pm 2.2^{\mathrm{bc}}$ & $30.2 \pm 1.1^{\mathrm{a}}$ & $221.1 \pm 86.9^{a}$ & $19.6 \pm 7.9^{\mathrm{ab}}$ & $2.4 \pm 0.8^{\mathrm{ab}}$ & $6.1 \pm 2.0^{\mathrm{a}}$ & $3.3 \pm 1.9^{\mathrm{a}}$ \\
\hline Family B & $31.3 \pm 2.5^{b c}$ & $31.0 \pm 1.4^{\mathrm{a}}$ & $156.7 \pm 73.6^{\mathrm{a}}$ & $11.4 \pm 5.6^{\mathrm{b}}$ & $4.1 \pm 1.4^{b}$ & $6.8 \pm 1.9^{a}$ & $4.2 \pm 2.0^{\mathrm{a}}$ \\
\hline Family H64 & $31.4 \pm 2.1^{b c}$ & $29.0 \pm 1.4^{\mathrm{a}}$ & $269.5 \pm 75.8^{\mathrm{a}}$ & $21.8 \pm 7.0^{\mathrm{ab}}$ & $2.6 \pm 0.8^{a b}$ & $5.8 \pm 1.7^{\mathrm{a}}$ & $3.2 \pm 1.2^{\mathrm{a}}$ \\
\hline Family J & $29.2 \pm 2.0^{\mathrm{abc}}$ & $29.1 \pm 1.1^{\mathrm{a}}$ & $327.4 \pm 105.8^{a b}$ & $32.2 \pm 11.7^{\mathrm{a}}$ & $1.8 \pm 0.8^{a}$ & $5.9 \pm 2.4^{a}$ & $5.0 \pm 2.4^{\mathrm{a}}$ \\
\hline Family M & $31.9 \pm 1.6^{b c}$ & $30.0 \pm 0.7^{\mathrm{a}}$ & $438.0 \pm 90.0^{b}$ & $29.0 \pm 6.2^{\mathrm{a}}$ & $2.7 \pm 0.8^{\mathrm{ab}}$ & $8.0 \pm 1.7^{\mathrm{a}}$ & $4.6 \pm 1.3^{a}$ \\
\hline Hybrid aspen in total & $30.8 \pm 0.9^{A}$ & $29.8 \pm 0.5^{A}$ & $294.5 \pm 40.9^{A}$ & $23.4 \pm 3.5^{\mathrm{A}}$ & $2.7 \pm 0.4^{\mathrm{A}}$ & $6.5 \pm 0.8^{A}$ & $4.0 \pm 0.7^{\mathrm{A}}$ \\
\hline European aspen & $26.0 \pm 1.6^{\mathrm{Ba}}$ & $26.2 \pm 0.8^{\mathrm{Ba}}$ & $258.7 \pm 69.9^{\mathrm{Aa}}$ & $27.2 \pm 5.9^{\mathrm{Aa}}$ & $2.0 \pm 0.4^{\mathrm{Aa}}$ & $5.8 \pm 2.0^{\mathrm{Aa}}$ & $4.6 \pm 2.0^{\mathrm{Aa}}$ \\
\hline
\end{tabular}

$\mathrm{DBH}$ - diameter at breast height.

Different capital letters indicate significant differences in mean values between hybrid aspen and European aspen.

Different small letters indicate significant differences between specific pairs of families at $\alpha=0.05$.
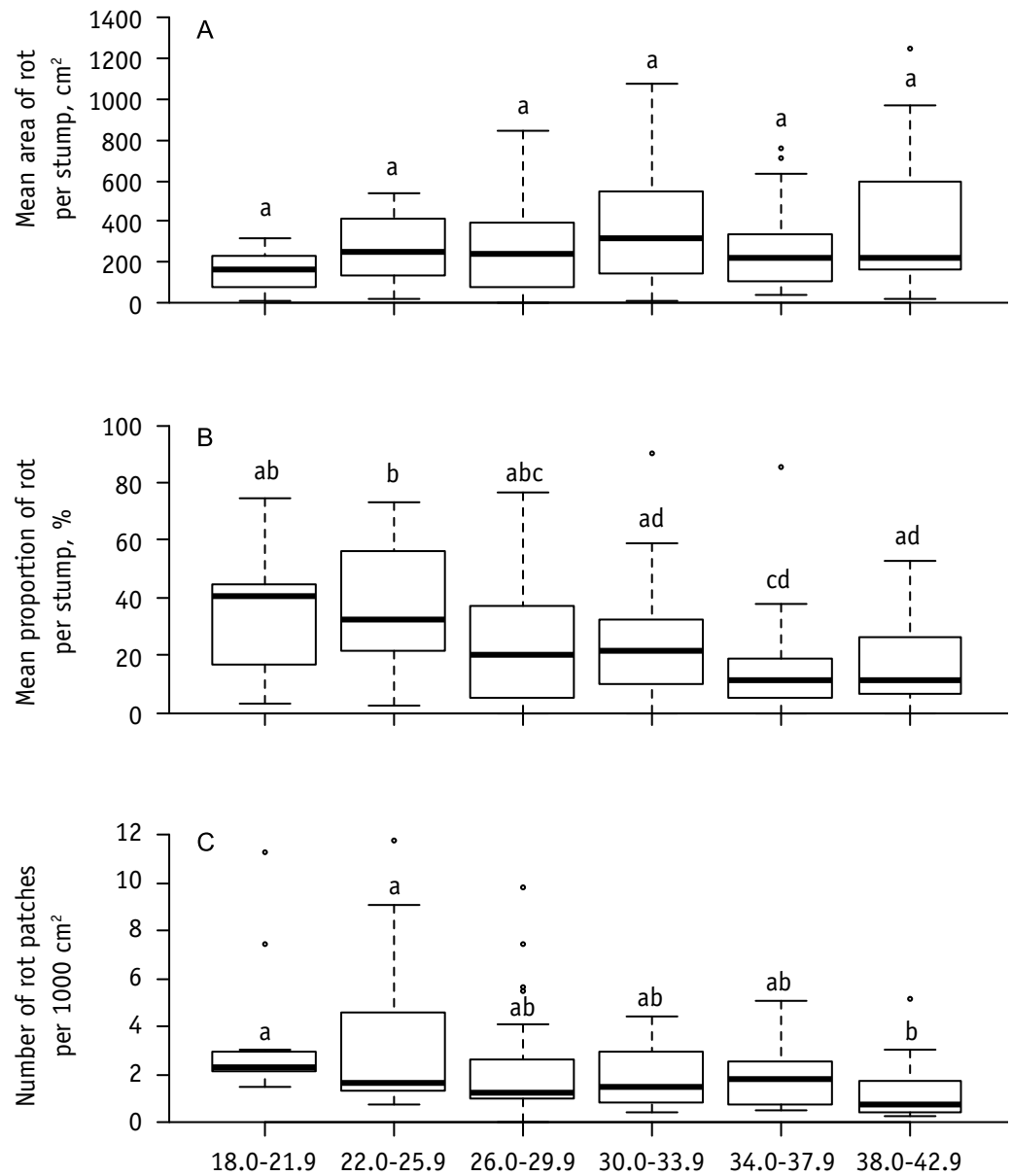

DBH groups

Figure 1. Mean area (A) and proportion (B) of rot per stump, and number of rot patches per $1000 \mathrm{~cm}^{2}(\mathrm{C})$ depending on DBH (diameter at breast height) of a tree (hybrid and European aspen together). Different letters indicate significant differences between specific pairs at $\alpha=0.05$. 


\section{Results}

The mean diameter of hybrid aspen significantly exceeded that of European aspen (Table 1). Regardless of the vigorous look of the stand, the heart rot and poplar borer galleries were abundant since they were found on 170 and 157 stumps out of the sampled 171, respectively.

The mean area and the proportion of rot was similar for both hybrid and European aspen ( $p=0.35$ and 0.08 , respectively) (Table 1). Nevertheless, the mean area of rot differed $(p=0.02)$ among the families, and the family $M$ exceeded families $A, B$ and H64, as well as European aspen (Table 1). Trees with larger DBH tended to have larger total rot area, but significantly $(p<0.01)$ smaller proportion of rot (Figure $1 \mathrm{~A}$ and B). In addition, family had significant effect on the proportion of rot $(p<0.01)$ (Table 1$)$.

The main part of rot was located in the centre of the stump and the peripheral rot area formed $9.2 \%$ of the total rot area. In total, $56.9 \%$ of the galleries were enclosed by the rot. The rot transferred exclusively by poplar borer damage (located around its galleries and not connected to other patches of rot on the stem cross-cut) was detected on 11 stumps (6.4\% of trees).

The number of galleries was similar for both hybrid and European aspen and also among families of hybrid aspen (Table 1). No significant correlation between damage by $S$. carcharias (number of galleries) nor rot (area of rot) and DBH (rho $=0.01, p=0.88$ and $r h o=0.11, p=0.13$, respectively) nor height $(r h o=0.01, p=0.85$ and $r h o=-0.01$, $p=0.86$, respectively) was found.

As expected, the number of galleries and number of rot patches correlated significantly ( $r h o=0.33, p<0.01)$. Significant correlation was also observed between the number of galleries and the total rot area (rho $=0.31, p<0.01)$.

Significant differences in number of rot patches were found among the families of hybrid aspen $(p=0.02)$ (Table 1$)$. The family B had significantly higher number of rot patches than the family J and European aspen (Table 1). Irrespectively of family, faster growing (greater DBH) trees had less rot patches per unit of area (rho $<-0.27, p=$ 0.01) (Figure 1C).

In total, rot occupied $24.3 \%$ of stump area, but area of galleries was negligible $(0.8 \%)$. However, damages were scattered and located close to the bark. The outermost rot and gallery was located at the 2.7 and $1.6 \mathrm{~cm}$ distance from the bark, respectively. Nonetheless, rot-free layer of sapwood was significantly $(p=0.04)$ wider for trees with larger DBH (Figure 2).

\section{Discussion}

Resistance to diseases may be interfered by hybridization in various ways. In our study, no significant differences of susceptibility of rot and poplar borer were found between hybrid and European aspen (Table 1). It is in accordance with Cheng et al. (2011) stating, that in most cases, hybrids are as resistant as or more susceptible than parental species.

No effect of rot area or number of galleries to the growth of trees was observed as suggested by non-significant correlation, although a negative effect of poplar borer damage on height growth has been reported by Cramer (1954) and Välimäki \& Heliövaara (2007). Reduction of growth might be a result of maintenance of high concentration of phenolic glycoside (Osier \& Lindroth, 2006), that has strong negative impact on herbivore growth, development time and fecundity (Osier \& Lindroth, 2001). Contrary, we found significant negative relationship between tree $\mathrm{DBH}$ and proportion and incidence of rot and galleries per unit of area (Figure 1C). Additionally, larger trees had wider rot-free layer from the bark (Figure 2). This could be explained by constant growth rate of rot regardless of tree size (Etheridge, 1961). However, Witt (2010) found positive relationship for tree $\mathrm{DBH}$ and both incidence and volume of 


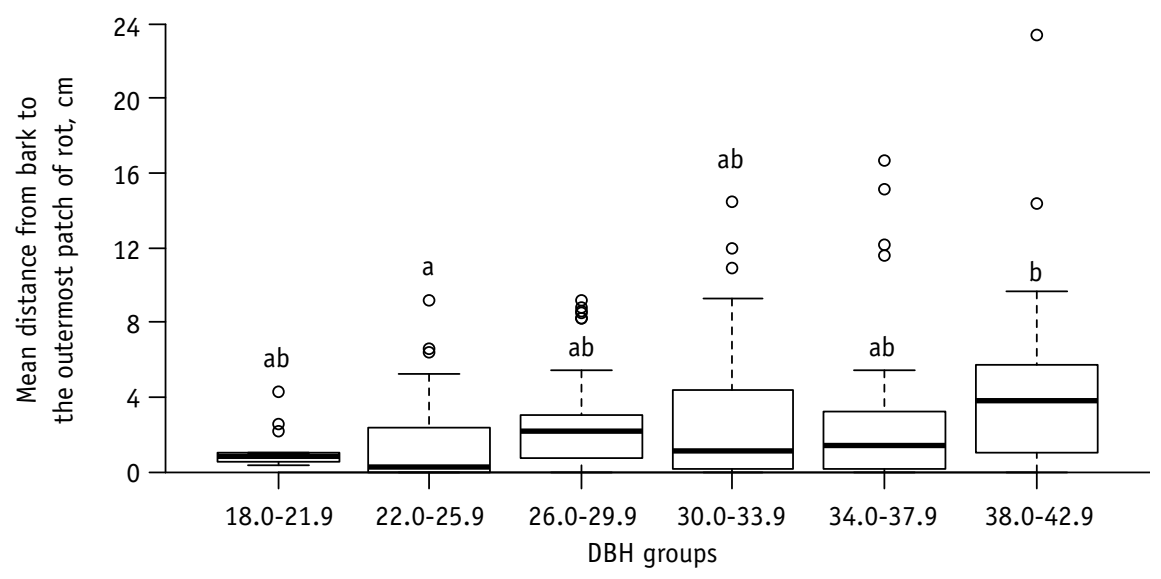

Figure 2. Mean distance from bark to the outermost patch of rot depending on DBH (diameter at breast height) of a tree (hybrid and European aspen together). Different letters indicate significant differences between specific pairs at $\alpha=0.05$.

infection. Alternatively, higher infestation of smaller trees by the poplar borer can be explained by its preference of young and small dimension trees (Nuorteva et al., 1981; Brandt et al., 2003).

Significant differences of damages were observed among hybrid aspen families (Table 1). This might be explained by genetically determined production of defence substances (Osier \& Lindroth, 2006). Alternatively, susceptibility against the rot might be explained by vessel features (wall-lumen ratio and size) that are partly genetically controlled and affect development of fungus (Eckstein et al., 1979). Poplar borer galleries might have similar effect, i.e. affecting aeration and loss of moisture, facilitating development of rot (Eckstein et al., 1979).

More intense infection of rot has been observed in stands damaged by boring insects (Newcombe et al., 2001). Hence, the number of galleries had significant effect on the number of patches and total area of rot. Although, the poplar borer is believed to damage young trees (Nuorteva et al., 1981), occurrence of galleries in sapwood suggested that this pest did not avoid also the older trees as observed by Välimäki \& He- liövaara (2007). The pest lives only within living wood, and hence it avoids heartwood rot by relocating closer to bark (Nuorteva et al., 1981). It explains the observed distribution of galleries in sapwood. Incidence of rot increases with the age of the tree (Witt, 2010) hence, at the age of 48 years rot was detected on $>99 \%$ of trees, regardless of their vigour.

\section{Conclusions}

Our hypothesis was not confirmed, and no significant difference of susceptibility between hybrid and European aspen was found. Alternatively, susceptibility to rot differed among the hybrid aspen families, hence hybrid aspen families as resistant to rot as European aspen might be selected.

Acknowledgements. Study was carried out in Latvian Council of Science project "Adaptive capacity of forest trees and possibilities to improve it" (No 454/2012). Comments of two anonymous reviewers helped to improve the manuscript. 


\section{References}

Brandt, J.P., Cerezek, H.F., Mallett, K.I., Volney, W.J.A., Weber, J.D. 2003. Factors affecting trembling aspen (Populus tremuloides Michx.) health in the boreal forest of Alberta, Saskatchewan, and Manitoba, Canada. - Forest Ecology and Management, 178, 287-300.

Cheng, D., Vrieling, K., Klinkhamer, P.G.L. 2011. The effect of hybridization on secondary metabolites and herbivore resistance: implications for the evolution of chemical diversity in plants. - Phytochemistry Reviews, 10, 107-117.

Cramer, H.H. 1954. Studies of the large poplar borer Saperda carcharias L. (Untersuchungen über den Grossen Pappelbock Saperda carcharias L.). Zeitschrift für Angewandte Entomologie, 35, 425458. (In German).

DeBell, D.S., Harrington, C.A., Clendenen, G.W., Zasada, J.C. 1997. Tree growth and stand development of four Populus clones in large monoclonal plots. - New Forests, 14, 1-18.

DeBell, D.S., Singleton, R., Harrington, C.A., Gartner, B.L. 2002. Wood density and fiber length in young Populus stems: relation to clone, age, growth rate, and pruning. - Wood and Fiber Science, 34, 529-539.

Eckstein, D., Liese, W., Shigo, A.L. 1979. Relationship of wood structure to compartmentalization of discolored wood in hybrid poplar. - Canadian Journal of Forest Research, 9, 205-210.

Etheridge, D.E. 1961. Factors affecting branch infection in aspen. - Canadian Journal of Botany, 39, 799-816.

Hynynen, J., Ahtikoski, A., Eskelinen, T. 2004. Yield and profitability of aspen plantation. (Viljelyhaavikon tuotos ja kasvatuksen kannattavuus). Metsätieteen aikakauskirja, 1, 113-116. (In Finnish).

Ilstedt, B., Gullberg, U. 1993. Genetic variation in a 26-year old hybrid aspen trial in southern Sweden. - Scandinavian Journal of Forest Research, 8, 185-192.

Mattson, W.J., Lawrence, R.K., Haack, R.A., Herms, D.A., Charles, P.J. 1988. Defensive strategies of woody plants against different insect-feeding guilds in relation to plant ecological strategies and intimacy of association with insects. - Mattson, W.J., Levieux, J., Bernard-Dagan, C. (eds). Mechanisms of woody plant defenses against insects. Springer-Verlag New York, 3-38.

Newcombe, G., Bradshaw, H. D. 1996. Quantitative trait loci conferring resistance in hybrid poplar to
Septoria populicola, the cause of leaf spot. - Canadian Journal of Forest Research 26, 1943-1950.

Newcombe, G., Ostry, M., Hubbes, M., Périnet, P., Mottet, M.J. 2001. Poplar diseases. - Dickmann, D., Isebrands, J.G., Eckenwalder, J.E., Richardson, J. (eds). Poplar Culture in North America. National Research Council, Canada, 249-276.

Nuorteva, M., Patomäki, J., Saari, L. 1981. Large poplar longhorn, Saperda carcharias (L.), as food for whitebacked woodpecker, Dendrocopos Leucotos (Bechst.) - Silva Fennica, 15, 208-221.

Osier, T.L., Lindroth, R.L. 2001. Effects of genotype, nutrient availability, and defoliation on aspen phytochemistry and insect performance. - Journal of Chemical Ecology, 27, 1289-1313.

Osier, T.L., Lindroth, R.L. 2006. Genotype and environment determine allocation to and costs of resistance in quaking aspen. - Oecologia, 148, 293-303.

R Core Team. 2016. R: A language and environment for statistical computing. R Foundation for Statistical Computing, Vienna, Austria. [WWW document]. URL https://www.R-project.org/ [Accessed 9 January 2017].

Rytter, L. Stener, L.G. 2005. Productivity and thinning effects in hybrid aspen (Populus tremula L. $\times$ P. tremuloides Michx.) stands in southern Sweden. Forestry, 78, 285-295.

Sokal, R.R., Rohlf, F.J. 1995. Biometry: The principles and practice of statistics in biological research. 3rd edition. W.H. Freeman, New York, 887 pp.

Šrot, M. 1962. Bionomics of poplar borer (Saperda carcharias L.) (Přispěvek k poznani bionomie kozlička topolového (Saperda carcharias L.)). - Reports of the Forest Research Institutes of Czechoslovakia, 25, 85-114. (In Slovenian).

Steenackers, J., Steenackers, M., Steenackers, V., Stevens, M. 1996. Poplar diseases, consequences on growth and wood quality. - Biomass and Bioenergy, 10, 267-274.

Tullus, A., Rytter, L., Tullus, T., Weih, M., Tullus, H. 2012. Short-rotation forestry with hybrid aspen (Populus tremula L. $\times$ P. tremuloides Michx.) in Northern Europe. - Scandinavian Journal of Forest Research, 27, 10-29.

Välimäki, S., Heliövaara, K. 2007. Hybrid aspen is not preferred by the large poplar borer (Saperda carcharias). - Arthropod-Plant Interactions, 1, 205-211.

Witt, C. 2010. Characteristics of aspen infected with heartrot: Implications for cavity-nesting birds. Forest Ecology and Management, 260, 1010-1016. 